\title{
Taking Responsibility: Supporting Schools to Support Children in Foster Care and State Custody
}

\author{
Jeffrey Alvin Anderson \\ Indiana University Bloomington \\ Rama Cousik \\ Indiana University - Purdue University Fort Wayne \\ Mary Jo Dare \\ Child Advocates (CASA) of Marion County \\ Indiana, USA
}

\begin{abstract}
For public schools that serve large percentages of young people who are at risk for school failure, the ability to fully engage families is widely considered a best practice. Recent research in the area of family-school partnerships indicates that increased family engagement has been associated with improvements in school outcomes such as academic performance. Although the term family is conceptually universal, its concise definition can be elusive because of the many meanings the word can connote. This paper examines conceptions of family for children who are in foster care. Additionally, suggestions are provided for community agencies and schools to work together to better support this population of young people. We argue that comprehensive approaches for supporting these young people to succeed educationally require effective interagency collaboration among schools and community-based agencies that serve children and families. Partnerships such as those found in Full Service Community Schools and systems of care are described as possible methods for implementing interagency collaboration in schools.
\end{abstract}

\section{Taking Responsibility: Supporting Schools to Support Children in Foster Care and State Custody}

Joey is 12 years old, in the sixth grade, and currently resides in the Candle Lake residential facility. Candle Lake is a live-in facility designed to serve young people under 21 years of age who are diagnosed with psychiatric challenges serious enough to require 
residential placement. Joey has been living there for four months. However, it is important to note that he was not placed there for psychiatric reasons. Although Joey does have some behavioral challenges, he was sent to Candle Lake after being removed from two foster care placements in quick succession, and the Child Welfare Department was unable to find an appropriate therapeutic foster home for him. Joey was first removed from his biological parents when he was seven years old. By that time, he had experienced a multitude of traumatic events including abuse and neglect, involvement in a very serious car accident, and the loss of a beloved uncle to suicide. Domestic violence in the family had been reported to the police several times. Additionally, the family had been homeless on numerous occasions, and Joey's mother continues to battle with substance abuse. His father was sent to prison several years ago for drug offenses and violence. From 8 until 10 years of age, Joey lived with a foster family, until his foster father passed away after a heart attack. Since then Joey has been suspended from school repeatedly and has lived in six different foster placements. He has an IQ that is slightly above average and does well academically when he is able to attend school, but he struggles to get along with his peers in social contexts. When he is not consumed with fits of anger, he gets along well with his teachers and other adults in his life. As might be expected, Joey has major trust issues. What should the school do to support Joey?

Children in foster care can have potentially chaotic experiences outside of the classroom. Thus, schools should endeavor to provide a consistent environment to help these young people be successful. Schools can provide structure, stability, and sameness, which are things that can be especially important for children who belong to highly mobile families or live in custodial care settings. Moreover, school personnel should recognize that prior trauma can adversely affect classroom behavior and academic performance. Schools also must understand that harsh and punitive disciplinary measures such as yelling, berating, and inappropriately using time-out and school suspension are ineffective and, for students with a history of trauma, can be psychologically detrimental (Mohr \& Anderson 2002). The above case example highlights some of the difficulties that Joey's school could counteract by providing supports such as: transportation, counseling, social skills training, anger management, and competence building (Cousik, 2011). Additionally, in this paper, the concept of family is explored from a distinct perspective: young people who are at high risk for or have been removed from their home of origin and placed into some form of state care, including foster care. Suggestions for schools and communities to better support young people in foster care and state custody are provided. According to the Adoption and Foster Care Analysis and Reporting System, in 2013 there were 402,378 children in foster care in the U. S. (Children's Bureau). Studies have shown that the trauma experienced by many of these children and youth can adversely impact their physical, psychological, mental, and social development (Leslie, et al., 2014). Compared to the general population, children and youth in out-of-home placements such as foster care are at higher risk for experiencing mental health and social challenges (Smyke, et al., 2014). For the victims of domestic abuse, parental neglect, and family substance abuse, problems can include eating disorders, mental and physical illnesses, intellectual disabilities, poor educational outcomes, malnutrition, social maladjustment, conduct disorders, and increased risk for incarceration. Furthermore, repeated separations from parents and foster parents also greatly increases the risks that these children will experience significant attachment and mood disorders and post-traumatic stress problems (Greeson et al., 2011; McMillen et al., 2004; Simms, Dubowitz, \& Szilagyi, 
2000). Thus, effective interventions to support youth in foster care must first acknowledge that many of these young people have experienced extensive trauma.

Researchers also have noted that mental and physical health risks for this group of young people can persist into adulthood, and therefore, comprehensive health care interventions that recognize and reduce these risks often are required (Zlotnick, Tam, \& Soman, 2012). In the field of children's mental health, for example, the principle of being "family-driven" has emerged as an essential component of treatment processes. This approach requires that services and supports be determined by caregivers in collaboration with professionals and tailored to the entire family unit, instead of just the child identified with mental health needs (Hunter \& Friesen, 1996; Stroul $\&$ Friedman, 1986). The underlying theoretical premise is that families are not only crucial to the treatment of their children's mental health issues (i.e., family-centered care), but caregivers need to be the central decision-makers (i.e., family-driven care) of all aspects of care. Caregivers are the primary facilitator of children's development and treatment cannot be separated from the environments in which mental health challenges occur. Indeed, for leading treatment processes, the objective is that families will become fully invested in interventions and treatment goals, thereby improving the probability of successful outcomes over time (Kuhlthau et al., 2011). Made popular through more than 30 years of wraparound and systems of care (SOC) research and development, family-driven care has changed the way in which services and supports are implemented (Bruns et al., 2010; Child Welfare; Walker \& Bruns, 2006). Professionals are less likely to blame families when caregivers are leading or at least partnering in intervention and change efforts (Anderson, 2016; Wright, Wright, Kooreman, \& Anderson, 2006).

\section{Background}

This paper is intended to help schools and their community partners better understand how to work with children who have been partially or fully removed from their families and placed with other families (e.g., foster care) or remanded into state custody. First, foster care systems and processes are described. Next, several existing models of interagency collaboration are presented as examples of how communities and schools can better work together. Finally, a set of recommendations is provided for communities, schools, and teachers to support the educational success of children and youth who are in foster care or state custody.

Such placements often are made through a legalistic process that occurs within the judicial (i.e., court) system. Decisions made by the court are administered by the child welfare system. These procedures often create situations in which it is unclear who constitutes a child's family. Moreover, children and youth can remain in highly itinerant living situations for months and even years, moving among parental, foster, and state custody. This situation causes challenges for the schools that educate these children since family engagement is both a required part of the IEP process and also a core component of many school reform efforts (Pushor, 2012; Henderson, Mapp, Johnson, \& Davies, 2007). At the same time, little information is available to help schools know how to guide family engagement for youth who are in state custody. Regardless, even without a clear understanding of "family" as it pertains to young people who are in placements away from their biological parents, schools still must provide the appropriate supports to ensure this group of students can be successful. 
Jeffrey Alvin Anderson et al.

\section{What Do We Mean by the Term "Family"?}

A central issue affecting young people in custodial care is understanding who constitutes the family. Although the concept of family is universal, it is surprisingly difficult to define in universally accepted terms (Gerson \& Torres, 2015; Treuthart, 1990). Inclusive notions of family require schools and others to recognize that a core family unit can include interconnected people who may or may not be living together and who may or may not be biologically related, within a host of contextual factors, including reciprocal and intersecting relationships in and among the home, community, and society (Bronfenbrenner, 1977). Moreover, because the basic concept of family is so common, misunderstandings may occur when school personnel work with families who do not appear to fit within typical definitions (e.g., biological parents who live together). At the same time, schools are required to recognize legal mandates about what constitutes a family, such as when biological parents are no longer allowed to make educational decisions because their children have been removed from parental custody. Some students will have no biological relatives in their family. For example, children may be orphaned or living with stepparents, neighbors, or with adopted parents. Children in families who are homeless or "home insecure" may be living with friends, in shelters, or on the street. Children may be living in highly mobile families, refugee camps, mental health or other residential facilities, or short and longer term foster placements. Like Joey from the case example, it is not uncommon for youth in foster care to live with several different family groups over time, sometimes even within the same school year. An important point for educators is that, regardless of the living arrangements or the nature or stability of a child's family structure, schools can be a constant for young people moving in and out of different home situations.

The challenge of engaging nontraditional families can be increased because many teachers are not trained or supported to work closely with families of any type (e.g., single, nuclear, extended, foster, temporary substitute care), and traditional contact between school and families often is limited to annual parent-teacher meetings or an annual Individualized Education Program (IEP) meeting if the student has an identified disability. Moreover, these meetings are typically held at the school, which can hinder caregiver involvement because they occur away from the familiar surroundings of home and community (see Cousik, 2015). School collaboration with parents/caregivers can be even more difficult when children are in foster care and/or have biological parents (or siblings) with mental health needs, or who are incarcerated, or who may be completely absent from a child's life (Bruskas, 2008). In such situations, caregivers may not be able to provide positive role models for their children and may be unavailable for any collaboration with the school. Teachers working with students in these situations need to understand how to engage the child welfare system and discern the appropriate caregiver with whom to engage.

\section{Foster Care}

Foster care has been defined as substitute care for children and youth who, for a variety of reasons, may have been removed, partially removed, or are at high risk of removal from their current homes (Federal Definition of Foster Care and Related Terms, 2015). The phrase "at risk" is included in this definition to highlight the fact that often foster care represents a continuum ranging from the youth living in a family home with one or both biological parents to the youth living in some form of residential setting because no secure home placement is available (McCarthy, Rider, Fawcett, \& Sparks, 2005). Some young people end up living in residential state custody because a stable foster placement cannot be found or sustained. The middle of this 
continuum includes children who are living in temporary to near permanent foster care, as well as youth in the process of being adopted. In a recent Washington Post weblog, Max Ehrenfreund (2015) quoted David Sanders, from Casey Family Programs in Seattle: "Foster care is sometimes necessary for the child's safety. Beyond a safe place to live, though, children need counseling, and ultimately, a permanent family that will care for them as they grow up." Without the presence of a permanent family, said Sanders, who oversees public policy for Casey, many young people will "repeat their parents' mistakes when they have kids of their own, perpetuating addiction, neglect and abuse to the next generation." Disrupting these generational patterns has become a focus of numerous family support programs. For example, the Nurse-Family Partnership program, in which nurses visit the homes of families living in poverty who have or are about to have a baby, reportedly reduces later child abuse and neglect by young mothers (MacMillan et al., 2009).

Legal standard. Foster care tends to be administered by child welfare, a governmental body that implements and oversees decisions made by the judicial system with legal mandate to remove children from their legal and often biological homes. Removal is based on ensuring the safety of a child or children living in a setting that is under investigation. The necessary level or legal standard for the child's safety is determined by the court, based on the findings of the investigation, and is usually conducted by a branch of the local child welfare agency (sometimes called child protective services). In addition to safety, foster care placement also involves two other goals: wellbeing and permanency. While permanency cannot be disconnected from either safety or wellbeing, it is widely agreed that children need a permanent place to live. Likewise, wellbeing is assumed to result from living in a place that is safe and permanent. Ultimately, the child welfare agency strives to find and sustain the correct balance among these three goals, with the overarching objective of keeping children with their biological families whenever possible. The countless possible outcomes of these efforts require schools to reexamine their notions of "family" and intensify their efforts to fully support young people who can be in a variety of unique living arrangements. It is also important to understand that although young people in the child welfare system often have and have had similar experiences, none of the situations will be identical.

Children in Need of Services. Typically, the avenues through which a young person enters the child welfare system involve a Child or Children in Need of Services (CHINS) petition. CHINS often are used for children under 18 years of age. How a CHINS functions differs from state to state. In Indiana, for example, a CHINS could be filed for a younger child based on abuse or neglect, homelessness, danger to self or others, truancy or other serious school-related problems (e.g., educational neglect), sexual crimes (victim or perpetrator), runaway, or parental issues (e.g., drug offenses). A CHINS also might be filed for a youth who gets involved with the juvenile justice system. Although CHINS filings often are concomitant to criminal cases, they are not themselves criminal in nature. First and foremost, the goal of a CHINS is to protect the child. Once filed, a caseworker from child welfare will be assigned to the case by the court overseeing the CHINS. Each step also includes due process procedures. The caseworker will investigate the reason for the CHINS: Was there substantiated abuse? Is the home environment safe? Are there other children in the home and, if so, are they safe? At this point, the family might be referred for family support services, for example, and a CHINS 
petition might not be not filed. Child welfare can work with the family for up to 6 months without a CHINS actually being filed.

When a CHINS is filed, the court will schedule a series of hearings. These include an initial hearing to find out what the parents want to do (e.g., deny or admit to the allegations). Denial will lead to a second, fact-finding hearing to provide the time and authority for child welfare to examine the case to either substantiate or drop the allegations. If proven, the next step is a dispositional hearing, during which the court will decide what needs to happen to protect the child; and, as much as possible, if and how the family can be supported to stay together. At this point, the court can: (a) order the child to be supervised by child welfare; (b) require treatment or interventions for the child and/or family; (c) move the child from the parent's home to foster care, a shelter facility, or other placement; (d) move custody from the parent to another adult or agency, including child welfare; or (e) partially or fully emancipate the child (Indiana Legal Services, 2015). When removal is imminent, the court will first look to place the youth with a relative or family friend. When siblings are involved, the court will work to keep them together. When a child has mental health concerns, the court will look for ways to provide therapeutic supports. Unfortunately, although therapeutic foster care has demonstrated positive effects for youth in foster care, demand is outpacing availability (Chamberlain, 2002). The court also may appoint a guardian ad litem or Court Appointed Special Advocate (CASA), whose primary role is to "advocate for the best interests of abused and neglected children in courtrooms and communities" (Court Appointed Special Advocates). These advocates are empowered by the courts to ensure that the rights and needs of children in foster care are addressed. The CASA works with a child until a permanent home is found. For many children, "a CASA volunteer is the only constant adult presence in their lives" (Court Appointed Special Advocates). Advocates also encourage communities to find a stable school environment to supplement the CASA for each participating child.

\section{Models of Interagency Collaboration in Schools and Communities}

Child- and family-serving agencies can work together with schools and with families to create comprehensive service structures that wrap necessary supports around youth and families in need (Anderson, 2011). Such interagency collaborations are critical if young people in custodial care are to succeed in school. Hartas (2004) defined collaboration as:

a dynamic system for educational efforts which endorses collegial, interdependent and co-equal styles of interaction between at least two partners... working together to achieve common goals in learning and decision-making processes that can be influenced by personal, ideological and organizational factors (p. 34).

Sometimes compared to a puzzle that, when completed makes a coherent whole picture, interagency collaboration requires each agency to be willing to merge or blur their own mission and vision with partner agencies and participants for the benefit of each child and family. Such objectives sound simple. However, because of the number of agencies that can be involved with a child, and with each bringing its own expertise, background knowledge, and ideology, conflicts can arise that create barriers to progress. For example, Darlington, Feeney, and Rixon (2005) examined factors that hinder interagency collaboration between child protective services and mental health services in cases in which a parent with a mental illness was involved and there 
were protection concerns for their children. Potential barriers to interagency collaboration identified through data analyses included: inadequate resources, confidentiality, gaps in interagency processes, unrealistic expectations, and professional knowledge domains and boundaries. In another example, Thompson and colleagues (2002) examined collaboration among staff in a home visiting program called the North Carolina Intensive Home Visitation Demonstration Project (HVDP). Initiated by the state of North Carolina in seven counties, HVDP provided collaborative services for new mothers who were living in low-income circumstances. The collaborating partners consisted of the home visitors, representatives from the health department, and other service providers such as counselors for the pregnant mothers or educational consultants who focused on developing school readiness skills in the children. Thompson et al. (2002) explored factors that facilitated and hindered collaboration among the agencies involved. They found that collaboration was facilitated by shared vision, role clarity, leadership, positive attitudes, and open communication among partners. On the other hand, factors that impeded collaboration included unresolved issues related to confidentiality, insufficient guidance about how to collaborate, lack of time and energy, and undisclosed competition among agencies.

\section{Systems of Care}

Anderson, Meyer, Sullivan, and Wright (2005) investigated how interagency collaboration created by a system of care (SOC) called the Dawn Project influenced children's social services in its community. The Dawn Project "was created in response to widespread dissatisfaction with the scope and quality of services available to vulnerable children and their families" (p. 512). According to Anderson et al. (2005), the importance of authentic family involvement at all levels of the service system and system-level coordination were the strongest themes that emerged from the study. On the other hand, challenges to successful implementation included notions of elitism and subversive resistance. The authors noted that social service agencies are well known for being grossly underfunded, and it was not surprising that there appeared to be a sense of resentment towards the Dawn Project SOC, which was quite well funded by a federal grant and local support and had caseloads that were far lower than in the traditional child welfare system. Resistance and widespread feelings of envy of the Dawn Project's success were also expressed as challenges by respondents of the study. The authors argued that resistance against any new, well-funded, large-scale initiative such as the Dawn Project should be anticipated because of the novel and unconventional methods it used.

\section{Full Purpose Partnership}

Another interagency collaborative model that has been implemented in schools is called the Full Purpose Partnership (FPP), an interagency collaboration between an urban school district and a local system of care (Crowley, Dare, Retz, \& Anderson, 2003). The FPP model requires each participating school to implement four essential elements: (a) effective curricula and instruction; (b) systems of care and wraparound principles (e.g., authentic family involvement, strengths-based practices, cultural competence, and interagency collaboration); (c) inquiry driven, data-based decision making; and (d) schoolwide positive behavior supports (Anderson, Houser, \& Howland, 2010; Smith, Anderson, \& Abel, 2008). Grounded in good teaching as the critical school practice, FPP creates and sustains ongoing opportunities for effective teaching and learning for all students through partnerships among school, home, and community. The emergence of the FPP model in a school is the responsibility of a School and 
Family Care Coordinator (SFCC), who works with the school faculty and leadership to the support academic development of all learners by connecting to outside resources as needed (e.g., housing, health, food pantries, mental health, adult literacy) (Anderson et al., 2010). The ultimate objective is always improved academic achievement.

\section{Full Service Community Schools}

Full Service Community Schools (FSCS) models, sometimes referred to as just community schools (Blank, Melaville, \& Shah, 2003), can include a wide range of supplementary supports, including educational (e.g., tutoring for standardized test prep), health (e.g., community mental health initiatives), recreational (e.g., after school programs), and family (e.g., caregiver literacy programs). These contemporary, broader-focused approaches have become popular in urban centers, recognizing that to successfully educate large numbers of atrisk students, connections to community resources (e.g., health, child welfare, psychological) are essential. Although the roots of this model can be traced back more than 100 years to John Dewey and Jane Adams, a more recent focus on FSCS by educational reformers has contributed to renewed recognition for the importance of building partnerships between schools and communities as necessary for improving academic achievement, particularly for children living in impoverished communities (Dryfoos, 2002; 2005). In fact, it has been argued that FSCSs offer a viable alternative to traditional schools because of their ability to fulfill the needs of students who may otherwise face difficulties due to socioeconomic constraints (Chen, Anderson, \& Watkins, 2016; Tagle, 2005).

According to the U. S. Department of Education (USDOE), "Full-Service Community Schools provide comprehensive academic, social, and health services for students, students' family members, and community members that will result in improved educational outcomes for children" (USDOE, 2014). In the FSCS model, the school becomes a central hub to attract a variety of community-based partnerships and funding, coordinated and designed to meet the specific contextual needs of the community and its children and families (Dryfoos, 2005; Voyles, 2012). Further, FSCS programs are intended to provide developmentally appropriate supports across the lifespan, thereby improving transitions from youth to adulthood. As Dryfoos (2002) noted, "almost anything can be provided in a school as long as it meets the needs of the school/community and as long as resources can be identified" (p. 397). The goal of this approach to school reform is to thoughtfully integrate fragmented and often inaccessible programs needed to support all young people and their families within a "one-stop" location in school buildings (Dryfoos \& Maguire, 2002).

\section{Recommendations}

\section{Communities}

Our primary recommendation is for each community to have a well-functioning CASA program in place. The CASA program or movement can be traced back to the mid-1970s, when a Superior Court Judge in Seattle, Washington started recruiting and training volunteers as appointed guardian ad litem to represent the interests of children (NCASAA, 2002). As noted, for too many children in these circumstances, the only stable adult in their life is a CASA. Because CASAs are independent of court control, these "citizen volunteers" can offer informed decision making that transcends the court policies and procedures and the child welfare system, to focus solely on the welfare of specific children (Collins-Camargo, Jones, \& Krusich, 2009; 
Litzelfelner, 2000). Some communities have also been using educational liaisons who work with youth in foster care and CASAs to assist specifically with educational issues and placements (Weinberg, Oshiro, \& Shea, 2014).

Second, while we put the onus for the success of young people in foster and substitute care on both the community and its schools, communities must create interagency platforms that allow schools and social service agencies to work more closely to meet the needs of students with multiple challenges. Not only do CASAs need a forum within which to work, interagency collaboration is a critical component of community-based services and supports (Winters \& Metz, 2013). One suggestion is to thoughtfully connect the System of Care and Full Service Community School models to create interagency collaboratives that can function simultaneously in both the school and community (Anderson \& Cornell, 2015). This is how the Full Purpose Partnership, described earlier, was started (Anderson et al., 2010). Further, such initiatives need to establish procedures to legally share confidential information. Darlington and colleagues (2005) recommended establishing clear protocols for information exchange, well documented and jointly developed case procedures, clear understandings of organizational constraints, and a sense of cohesion among systems and agencies. Thompson et al. (2002) recommended developing guidelines for service delivery objectives and collaborative processes that would help everyone understand the amount of time and commitment required for effective collaboration. These authors also suggested that to improve interagency collaboration, communities will need to closely examine and confront the root causes of conflict among different family-serving agencies. Their ultimate recommendation was to break down "ideological and professional barriers" (p. 63), by providing sufficient time for collaboration, creating appropriate policies and procedures for collaboration, sharing resources, and greatly improving communication among systems and agencies (Anderson et al., 2005; 2010).

Our third recommendation for better supporting youth in foster care is that communities use team-based approaches to put interagency collaboration into practice. Specifically, community-based multisystem collaborations (e.g., child welfare, health care, juvenile justice, education) should include family members, service providers, school personnel, and as appropriate, participating youth on each child and family team (Wright et al, 2006). These teams would identify and monitor progress toward common goals and objectives (e.g., improved academic performance, reduced aggression against peers) (Anderson, 2011). Moreover, to avoid gaps, duplications, misunderstandings, etc., community leaders must insist that all necessary partners participate in the teaming processes. As noted, ongoing interagency communication is essential (Thompson et al., 2002). Such teams typically consist of the youth, family members, people who support the youth and/or family (e.g., friends, members of the church), teachers, and representatives from agencies that are involved with the youth and family (Anderson \& Matthews, 2001; Winters \& Metz, 2013).

The team brings together different sources of expertise and resources to bear on identified goals and objectives (Walker \& Schutte, 2005). These comprehensive, multisystem plans focus on home, community, and school, and would connect to the IEP for students who are receiving special education services. Child and family or "wrap teams" as they are sometimes called, are intended to be flexible enough to respond to individual circumstances while encouraging caregivers and young people themselves to lead treatment processes (Walker \& Bruns, 2006). The long-term objective is that the young person will eventually be responsible for managing her or his own long term outcomes (Bruns et al., 2010). 


\section{Trauma informed interventions}

Given the complex issues facing children in foster care, and to ensure that these children achieve positive school outcomes, we also recommend that schools and teachers provide "trauma informed care and support" (Greeson et al., 2011). As part of the interagency collaborative approaches described earlier, schools need to partner with local welfare and mental health agencies to create safe spaces for traumatized children to participate in academic learning, engage meaningfully in leisure time with peers, and for secondary students, to pursue creative/vocational/career related activities. As Morrison and her colleagues (2015) noted, "Trauma survivors not only struggle to function within societal boundaries, but they are also often slow to trust those who might help them and are particularly vulnerable to unintended revictimization" (p. 2). The authors describe core principles of trauma informed care for organizations as including: (a) supporting trauma survivors and ensuring they are not inadvertently re-traumatized by the care that is provided; (b) understanding trauma and its effects and how survivors' coping mechanisms can manifest in challenging behaviors; (c) providing physically and emotionally safe environments; (d) empowering trauma survivors to participate in developing and implementing their own treatment plans; and (e) assisting trauma survivors to understand, develop, and harness their personal strengths. Assisting schools to understand and adopt supports that are sensitive to these principles seems like a reasonable place for communitybased interagency initiatives to start (see Anderson, 2016; SAMHSA, 2014).

Schools. For schools, we start by recommending that the school leadership take ownership for all students in their buildings, including students who may be in foster or substitute care. The goal for these students should be school stability and both short- and longterm emphases on positive school outcomes (e.g., appropriate adult and peer relationships; high school graduation). We recognize that this puts a strain on schools, but we cannot overstate the importance of supporting students who may not have a stable family in their life to stay in school. To implement this recommendation, school leadership needs to ensure that school personnel have the adequate time to be part of the collaborative teaming processes previously described (Anderson, 2011). Moreover, because schools have the option to be somewhat flexible with what they do during, before, and after the 6.5-hour school day, we recommend that interagency teams make use of this flexibility. For example, after-school programs can support academic development by offering homework help. This can assist single parents and other busy caregivers who may be unable to provide educational and psychological support at home. Educators also must identify and understand the antecedents and reinforcement patterns of challenging behaviors instead of relying on punitive responses that, at best, provide only temporary relief to symptomatology (Mohr \& Anderson, 2002). Well-conducted functional behavioral assessments provide educators with needed information about the causes and contributors to problem behavior that allow for development, implementation, and monitoring of positive behavior plans (Benner, Kutash, Nelson, \& Fisher, 2013). Apart from mental health issues, many children and youth in foster care also present with developmental delays, intellectual disabilities, and attention deficit hyperactivity disorders and will need supports at home to reinforce concepts learned in school. The Full Service Community Schools approach offers a model through which schools can simultaneously offer supports to children, teachers, and substitute caregivers by providing important social services in the school (Min, Anderson, \& Chen, in press). 
To address social and behavioral challenges in general, many schools are choosing to implement Positive Behavior Interventions and Supports (PBIS). According to the Office of Special Education Programs (OSEP), "PBIS is a framework or approach for assisting school personnel in adopting and organizing evidence-based behavioral interventions into an integrated continuum that enhances academic and social behavior outcomes for all students. PBIS is a prevention-oriented way for school personnel to (a) organize evidence-based practices; (b) improve their implementation of those practices; and (c) maximize academic and social behavior outcomes for students" (Positive Behavior Interventions and Supports). PBIS endeavors to ensure that all students are successful in school. In coming years, the field will likely see a shift from PBIS and Response to Intervention (RtI) to Multi-tiered Systems of Support (MTSS) that are more comprehensive and integrate academic, social, and behavioral data-driven outcomesbased supports systems (Algozzine et al., 2012; Anderson, \& Cornell, 2015; Benner et al., 2013).

Teachers. We hesitate to put any additional pressure on teachers; however, the following recommendations for working with students in foster care also reflect good teaching in general: (a) be flexible, strength-based, and resiliency-focused (Hass \& Graydon, 2009); (b) ensure that teaching is relevant and engaging; (c) build authentic relationships in the classroom, including student-teacher and peer-to-peer; and (d) work closely with interagency team members and identified caregivers (Anderson \& Cornell, 2015); (e)implement simple but powerful approaches such as the 40 developmental assets. Survey data from "more than 4 million children and youth from all backgrounds and situations has consistently demonstrated that the more Developmental Assets young people acquire, the better their chances of succeeding in school and becoming happy, healthy, and contributing members of their communities and society" (Search Institute).

Teachers also need to rethink other aspects of classroom practice when working with students in foster care. For example, in terms of homework expectations, a guiding question for teachers can be, "Is it reasonable to expect academic homework from this child?" And finally, teachers should always ask themselves under what conditions is suspension and expulsion appropriate for young people in foster care? Indeed, such disciplinary responses can rapidly put foster placements in jeopardy when they place added and perhaps unexpected pressure on the home environment. Such strategies should be used only under extremely controlled conditions and with the involvement of the interagency team (Mohr \& Anderson, 2002).

\section{Conclusion}

In closing, we recommend that communities and schools explore programs that are being developed to promote positive outcomes for youth in foster care (e.g., Foster, Saunders, \& Summerfelt. 1996). For example, Philips et al. (2015) describe two such programs that offer transitions to college: the transition to college camp by Michigan State University (Kirk \& Day, 2011) and the Foster Care to College Partnership initiative in Washington State (Burley, 2009). Both appear promising for improving adult outcomes for youth who have grown up in the foster care system. The authors also describe their own Better Futures program at Portland State University (Phillips et al., 2015), which "features a four day on-campus Summer Institute, coaching provided to youth by older peers who are in college and have shared experiences around foster care and/or mental health, and workshops that bring together youth, coaches and guest speakers for information sharing and mutual support" (p 50). 
Finally, while we are loath to recommend any sort of a re-centralizing of residential services for children at high risk for substitute care, at least in some ways, this is exactly what is currently occurring. Facilities that were created for children with psychiatric problems too often are the de facto housing for children who lack longer term stable living placements. However, such settings were not designed to support young people who have been removed from their home. Therefore, at the risk of appearing to recommend a form of re-institutionalization (e.g., orphanages), we ponder whether creating temporary but highly nurturing "places" might be warranted for those youth who are hopelessly mired in legal and foster care systems that lack therapeutic, permanent placement options. Such residentially developed supports could include intensive mental health supports, seamless and supportive connections with foster families, supports for keeping kids in stable, inclusive, educational settings, and support for adoptive families (e.g., mentoring, emotional support, respite care). Regardless, at a minimum, we call on communities to support these children appropriately and reiterate that despite the challenges faced in securing long-term living permanency, ensuring successful school engagement for these youth provides an essential protective factor (Anderson, 2016; Phillips et al., 2015). 


\section{References}

Algozzine, B., Wang, C., White, R., Cooke, N., Marr, M. B., Algozzine, K., \& Duran, G. Z. (2012). Effects of multi-tier academic and behavior instruction on difficult-to-teach students. Exceptional Children, 79(1), 45-64.

Anderson, J. A. (2011). Patterns of school functioning over time among students served in a system of care. Remedial and Special Education, 32(6), 482-495.

Anderson, J. A. (2016). Is an ounce of prevention still worth a pound of cure? Community-based interagency collaboration to enhance student and family wellbeing. School Community Journal, 26(1), 9-29.

Anderson, J. A., \& Cornell, H. (2015). Full Service Community Schools: A comprehensive education model for providing comprehensive supports for students and their families. In 8th Annual International Conference of Education, Research and Innovation, ICERI2015. Retrieved from http://library.iated.org/view/ANDERSON2015FUL

Anderson, J. A., Houser, J., \& Howland, A. (2010). The Full Purpose Partnership model for promoting academic and socio-emotional success in schools. The School Community Journal, 20(1), 31-53. Retrieved from http://files.eric.ed.gov/fulltext/EJ891831.pdf

Anderson, J. A. \& Matthews. B. (2001). We care for students with emotional and behavioral disabilities and their families. Teaching Exceptional Children, 33(5), 34-39.

Anderson, J. A., Meyer, R. D., Sullivan, W. P., \& Wright, E. R. (2005). Impact of a system of care on a community's children's social services system. Journal of Child and Family Studies, 14(4), 505-520.

Benner, G. J., Kutash, K., Nelson, J. R., \& Fisher, M. B. (2013). Closing the achievement gap of youth with emotional and behavioral disorders through multi level systems of support. Education and Treatment of Children, 36(3), 15-30.

Blank, M. J., Melaville, A., \& Shah, B. P. (2003). Making the difference: Research and practice in community schools: Coalition for Community Schools. Retrieved from http://www. communityschools.org/mtdhomepage.html

Bronfenbrenner, U. (1977). Toward an experimental ecology of human development. American Psychologist, 32(7), 513.

Bruns, E. J., Walker, J. S., Zabel, M., Matarese, M., Estep, K., Harburger, D., Pires, S. A. (2010). Intervening in the lives of youth with complex behavioral health challenges and their families: The role of the wraparound process. American Journal of Community Psychology, 46(3-4), 314-331. 
Bruskas, D. (2008). Children in foster care: A vulnerable population at risk. Journal of Child and Adolescent Psychiatric Nursing, 21(2), 70-77.

Burley, M. (2009). Foster care to college partnership: Evaluation of education outcomes for foster youth. Washington State Institute for Public Policy, Olympia, WA (2009). Retrieved from http://www.wsipp.wa.gov.ezproxy.library.ipfw.edu/ReportFile/1060

Chamberlain, P. (2002). Treatment foster care. In B. J. Burns \& K. Hoagwood (Eds.), Community treatment for youth: Evidence-based interventions for severe emotional and behavioral disorders. (pp. 117-138). New York: Oxford University Press.

Chen, M. E., Anderson, J. A., \& Watkins, L. (2016). Parent perceptions of connectedness in a full service community school project. Journal of Child and Family Studies, 25(7), 22682278. DOI 10.1007/s10826-016-0398-5.

Children's Bureau. Retrieved from https://www.acf.hhs.gov/sites/default/files/cb/afcarsreport21.pdf

Child Welfare. History of System of Care. Retrieved from ttps://www.childwelfare.gov/topics/management/reform/soc/history/history/

Collins-Camargo, C., Jones, B. L., \& Krusich, S. (2009). What do we know about strategies for involving citizens in public child welfare: A review of recent literature and implications for policy, practice, and future research. Journal of Public Child Welfare, 3(3), 287-304. DOI: $10.1080 / 15548730903129954$

Court Appointed Special Advocates (CASA). Retrieved from http:/www.casaforchildren.org/site/c.mtJSJ7MPIsE/b.5301295/k.BE9A/Home.htm

Cousik, R. (2011). A case study of four children with multiple risk factors in a music class (Doctoral dissertation). Retrieved from http://gradworks.umi.com/34/81/3481387.html. (3481387).

Cousik, R. (2015). Cultural and functional diversity in the elementary classroom: Strategies for teachers. Journal for Multicultural Education, 9(2), 54-67.

Crowley, M. F., Dare, M. J., Retz, J., \& Anderson, J. A. (2003). Who said it couldn't be done? Creative response from flagrant site and special education. In Winter 2003 System of Care Community Meeting: "Education: A System of Care Partner-Effective Strategies for Serving Youth with Serious Emotional Disorders and Their Families." CMHS, U. S. Dept. of Health and Human Services, Portland, OR.

Darlington, Y., Feeney, J. A., \& Rixon, K. (2005). Interagency collaboration between child protection and mental health services: Practices, attitudes and barriers. Child Abuse \& Neglect, 29(10), 1085-1098. 
Supporting Children in Foster Care

Dryfoos, J. (2002). Full-service community schools: Creating new institutions. Phi Delta Kappan, 83(5), 393.

Dryfoos, J. (2005). Full-service community schools: A strategy—not a program. New Directions For Youth Development, 107, 7-14.

Dryfoos, J. G., \& Maguire, S. (2002). Inside Full-service Community Schools. Thousand Oaks, CA: Corwin Press.

Ehrenfreund, M. (2015). The bipartisan plan to save foster care. Retrieved from https://www.washingtonpost.com/news/wonk/wp/2015/08/31/the-bipartisan-plan-to-savefoster-care/

Federal Definition of Foster Care and Related Terms [Code of Federal Regulations] [Title 45, Volume 4, Parts 1200 to End] [Revised as of October 1, 2000]. From the U. S.

Government Printing Office via GPO Access [CITE: 45CFR1355.20]. Retrieved from http://www.dhs.state.mn.us/main/idcplg?IdcService=GET_FILE\&RevisionSelectionMet hod $=$ LatestReleased \&Rendition $=$ Primary\&allowInterrupt $=1 \&$ noSaveAs $=1 \& \mathrm{dDocName}=$ dhs_id_027331

Foster, E. M., Saunders, R., \& Summerfelt, W. T. (1996). Foster care to college partnership: Evaluation of education outcomes for foster youth. Washington State Institute for Public Policy, Olympia, WA (2009). Retrieved from http://www.wsipp.wa.gov.ezproxy.library.ipfw.edu/ReportFile/1060

Gerson, K. \& Torres, S. (2015). Changing family patterns. emerging trends in the social and behavioral sciences: An interdisciplinary, searchable, and linkable resource, 1-15. Retrieved from: http://onlinelibrary.wiley.com/doi/10.1002/9781118900772.etrds0037/full

Greeson, J. K., Briggs, E. C., Kisiel, C. L., Layne, C. M., Ake III, G. S., Ko, S. J., Pynoos, R. S. (2011). Complex trauma and mental health in children and adolescents placed in foster care: Findings from the National Child Traumatic Stress Network. Child Welfare, 90(6), 91-108.

Hartas, D. (2004). Teacher and speech-language therapist collaboration: Being equal and achieving a common goal? Child Language Teaching \& Therapy, 20(1), 33-54.

Hass, M. \& Graydon, K. (2009). Sources of resiliency among successful foster youth. Children and Youth Services Review, 31(4), 457-463.

Henderson, A. T., Mapp, K. L., Johnson, V. R., \& Davies, D. (2007). Beyond the bake sale: The essential guide to family-school partnerships. New York, NY: The New Press. 
Hunter, R. W., \& Friesen, B. J. (1996). Family-centered services for children with emotional, behavioral, and mental disorders. In C. A. Heflinger \& C. Nixon (Eds.), Families and mental health services for children and adolescents (pp. 18-40). Newbury Park: Sage.

Indiana Legal Services. Retrieved from http://www.indianalegalservices.org/node/56/generalinformation-about-chins\#sthash.sruzs30C.dpuf.

Kirk, R. \& Day. A. (2011). Increasing college access for youth aging out of foster care:

Evaluation of a summer camp program for foster youth transitioning from high school to college. Children and Youth Services Review, 33(7).

doi:10.1016j.childyouth.2011.02.018.

Kuhlthau, K. A., Bloom, S., Van Cleave, J., Knapp, A. A., Romm, D., Klatka, K., Perrin, J. M. (2011). Evidence for family-centered care for children with special health care needs: a systematic review. Academic Pediatrics, 11(2), 136-143.

Leslie, L. K., Hurlburt, M. S., James, S., Landsverk, J., Slymen, D. J., \& Zhang, J. (2014). Relationship between entry into child welfare and mental health service use. Psychiatric Services, 56(8), 981-987.

Litzelfelner, P. (2000). The effectiveness of CASAs in achieving positive outcomes for children. Child Welfare, 79(2). 179-193.

MacMillan, H. L., Wathen, C. N., Barlow, J., Fergusson, D. M., Leventhal, J. M., \& Taussig, H. N. (2009). Interventions to prevent child maltreatment and associated impairment. The Lancet, 373(9659), 250-266.

McCarthy, J., Rider, F., Fawcett, C. M., \& Sparks, S. (2005). Services for youth in the child welfare system and their families in systems of care. In B. Stroul \& G. Blau (Eds)., The System of Care Handbook (pp. 595-617). Baltimore, MD: Brooks Publishing.

McMillen, J. C., Scott, L. D., Zima, B. T., Ollie, M. T., Munson, M. R., \& Spitznagel, E. (2004). Use of mental health services among older youths in foster care. Psychiatric Services, 55(7), 811-817.

Min, M., Anderson, J. A., \& Chen, M. E. (in press). Full service community schools: Integrative literature review using Nvivo. School Community Journal.

Mohr, W. K., \& Anderson, J. A. (2002). Reconsidering punitive and harsh discipline. The Journal of School Nursing, 18(6), 346-352.

Morrison, M., Alcantara, A., Conover, K., Salerno, A., Cleek, A., Parker, G., McKay, M., Sharp, C., \& Ligenza, L. (2015). Harnessing the learning community model to integrate trauma informed care principles in service organizations. New York: The McSilver Institute for Poverty Policy And Research: New York University, Silver School of Social Work. 
National Court Appointed Special Advocates Association (NCASAA). (2002). CASA: A guide to program development. Retrieved from http://nc.casaforchildren.org/files/public/community/programs/Guides-Manuals/Guideto-program-development-2002.pdf

Phillips, L. A., Powers, L. E., Geenen, S., Schmidt, J., Winges-Yanez, N., McNeely, I. C., Zweben, H. (2015). Better Futures: A validated model for increasing postsecondary preparation and participation of youth in foster care with mental health challenges. Children and Youth Services Review, 57, 50-59.

Positive Behavior Interventions and Supports. Retrieved from http:/www.pbis.org/

Pushor, D. (2012). Tracing my research on parent engagement: Working to interrupt the story of school as protectorate. Action in Teacher Education, 34(5-6), 464-479.

Search Institute. Retrieved from http://www.search-institute.org/research/developmental-assets

Substance Abuse and Mental Health Services Administration (SAMSHA) Trauma and Justice Strategic Initiative (2014). SAMHSA's concept of trauma and guidance for a traumainformed approach. HHS Publication No. SMA 14-4884. Rockville, MD.

Simms, M. D., Dubowitz, H., \& Szilagyi, M. A. (2000). Health care needs of children in the foster care system. Pediatrics, 106(3), 909-918.

Smith, S. J., Anderson, J. A., \& Abel, A. K. (2008). Preliminary evaluation of the full purpose partnership school-wide model. Preventing School Failure, 53(1), 28-37.

Smyke, A. T., Zeanah, C. H., Gleason, M. M., Drury, S. S., Fox, N. A., Nelson, C. A., \& Guthrie, D. (2014). A randomized controlled trial comparing foster care and institutional care for children with signs of reactive attachment disorder. The American Journal of Psychiatry, 60(5), 508-514.

Stroul, B. A., \& Friedman, R. M. (1986). A System of Care for Severely Emotionally Disturbed Children \& Youth. Retrieved from http://eric.ed.gov/?id=ED330167

Tagle, R. (2005). Full-service community schools: Cause and outcome of public engagement. New Directions for Youth Development, 2005(107), 45-54.

Thompson, D., Socolar, R., Brown, L., \& Haggerty, J. (2002). Interagency collaboration in seven North Carolina counties. Journal of Public Health Management \& Practice, 8(5).

Treuthart, M. P. (1990). Adopting a more realistic definition of family. Gonzaga Law Review, 26, 91.

U.S. Department of Education. (2014). Full Service Community Schools Program. Retrieved from http://www2.ed.gov/programs/communityschools/index.html. 
Voyles, M. M. (2012). Perceived needs of at-risk families in a small town: Implications for fullservice community schools. School Community Journal, 22(2), 31-63.

Walker, J. S., \& Bruns, E. J. (2006). Building on practice-based evidence: Using expert perspectives to define the wraparound process. Psychiatric Services, 57(11), 1579-1585.

Walker, J. S., \& Schutte, K. (2005). Quality and individualization in wraparound team planning. Journal of Child and Family Studies, 14(2), 251-267.

Weinberg, L. A., Oshiro, M., \& Shea, N. (2014). Education liaisons work to improve educational outcomes of foster youth: A mixed methods case study. Children and Youth Services Review, 41, 45-52.

Winters, N. C. \& Metz, P. (2013). The wraparound approach in systems of care. Psychiatric Clinics of North America, 32(1), 135-151.

Wright, E. R., Russell, L. A., Anderson, J. A., Kooreman, H. E., \& Wright, D. E. (2006). Impact of team structure on achieving treatment goals in a system of care. Journal of Emotional and Behavioral Disorders, 14(4), 240-250.

Wright, E. R., Wright, D. E., Kooreman, H. E., \& Anderson, J. A. (2006). The nature and impact of conflict within service coordination teams for children and adolescents with serious emotional and behavioral challenges. Administration and Policy in Mental Health and Mental Health Services Research, 33(3), 302-315.

Zlotnick, C., Tam, T. W., \& Soman, L. A. (2012). Life course outcomes on mental and physical health: The impact of foster care on adulthood. American Journal of Public Health, 102(3), 534-540. 